\title{
Changes in serum albumin and other nutritional markers when using sucroferric oxyhydroxide as phosphate binder among hemodialysis patients: a historical cohort study
}

Kamyar Kalantar-Zadeh', Linda H. Ficociello², Vidhya Parameswaran², Nicolaos V. Athienites ${ }^{3}$, Claudy Mullon $^{2}$, Robert J. Kossmann ${ }^{2}$ and Daniel W. Coyne ${ }^{4^{*}}$ (D)

\begin{abstract}
Background: Elevated serum phosphorus concentrations are common among maintenance hemodialysis patients. Protein is a major source of dietary phosphate, but restriction of protein intake can result in hypoalbuminemia and protein-energy wasting. We hypothesized that sucroferric oxyhydroxide (SO), a potent phosphate binder with a low pill burden, may reduce serum phosphorus levels in hemodialysis patients with hypoalbuminemia without adversely impacting albumin levels or dietary intake of protein.

Methods: We retrospectively examined de-identified data from 79 adult, in-center hemodialysis patients with baseline hypoalbuminemia $(\leq 3.5 \mathrm{~g} / \mathrm{dL}$ ) switched to $\mathrm{SO}$ as part of routine clinical care for at least 1 year. Temporal changes (3-month intervals from baseline through Q4) in phosphate binder pill burden, serum phosphorous levels, nutritional markers, and equilibrated Kt/N were analyzed. Data from a matched reference group of nonhypoalbuminemic patients $(N=79)$ switched to SO were also examined.

Results: SO therapy was associated with a mean reduction of 45.7 and $45.1 \%$ in daily phosphate binder pill burden, and a mean reduction of $0.4 \mathrm{mg} / \mathrm{dL}$ and $0.51 \mathrm{mg} / \mathrm{dL}$ in serum phosphorus levels for the hypoalbuminemic and nonhypoalbuminemic patients, respectively. Hypoalbuminemic patients demonstrated significant increases in mean serum albumin levels from $3.50 \mathrm{mg} / \mathrm{dL}$ at baseline to $3.69,3.74,3.70$, and $3.69 \mathrm{mg} / \mathrm{dL}$ during Q1 through Q4, respectively $(P<0.0001)$, whereas serum albumin levels remained unchanged in the non-hypoalbuminemic group.
\end{abstract}

Conclusions: Both hypoalbuminemic and non-hypoalbuminemic patients switching to SO exhibited significant reductions in serum phosphorus concentrations and daily phosphate binder pill burden. Among hypoalbuminemic patients, the initiation of SO therapy was also associated with increases in serum albumin, suggesting therapy may have allowed patients to increase their dietary intake of protein.

Keywords: Hemodialysis, Albumin, Sucroferric oxyhydroxide, Phosphorous, Phosphate binder

\footnotetext{
* Correspondence: dcoyne@wustl.edu

${ }^{4}$ Washington University School of Medicine, 660 S. Euclid Ave., CB 8129, St.

Louis, MO 63110, USA

Full list of author information is available at the end of the article
}

(c) The Author(s). 2019 Open Access This article is distributed under the terms of the Creative Commons Attribution 4.0 International License (http://creativecommons.org/licenses/by/4.0/), which permits unrestricted use, distribution, and reproduction in any medium, provided you give appropriate credit to the original author(s) and the source, provide a link to the Creative Commons license, and indicate if changes were made. The Creative Commons Public Domain Dedication waiver (http://creativecommons.org/publicdomain/zero/1.0/) applies to the data made available in this article, unless otherwise stated. 


\section{Background}

More than one-third of chronic kidney disease patients undergoing hemodialysis (HD) have serum phosphorus (sP) levels $>5.5 \mathrm{mg} / \mathrm{dL}$ [1]. The interplay among protein intake, sP, and serum albumin (sAlb) levels raises a clinical conundrum when managing patients' sP. Hyperphosphatemia and hypoalbuminemia are independent risk factors for mortality among dialysis patients, thus clinicians may be wary of correcting one risk factor at the "expense" of the other [2-5]. Reducing dietary protein consumption, while limiting phosphate intake, can result in reduced sAlb, decreased normalized protein catabolic rate (nPCR), and protein-energy wasting (PEW). These PEW parameters have been associated with increased mortality and reduced quality of life among HD patients [4-10]. For example, the reduction of both sP and sAlb has been associated with a $26 \%$ increase in mortality (relative to increases in both parameters) [4]. The relationship between sP and sAlb may be further confounded by the gastrointestinal side effects of some phosphate binders (PBs) [11], which may impair appetite and protein intake. Additionally, use of less effective PB therapy may lead to more dietary restrictions in an attempt to control sP, leading to lower dietary protein intake, higher likelihood of PEW, and poor outcomes $[12,13]$.

Sucroferric oxyhydroxide (SO; VELPHORO ${ }^{\circ}$ [Fresenius Medical Care Renal Therapies Group, Waltham, MA, USA]) is a potent PB indicated for the control of sP in dialysis patients, with a starting dose of 3 tablets/day. SO is a non-calcium, chewable, iron-based agent with high phosphate-binding capacity and a starting dose of 3 tablets/day $(1500 \mathrm{mg}$ daily) $[14,15]$. Over the 1-year follow-up period of a 24-week phase 3 trial and associated 28-week extension study, control of sP was achieved with markedly reduced mean SO pill burden when compared to sevelamer (3.3 vs 8.7 tablets per day) [16]. Retrospective analyses of patients switched from another PB to SO have also demonstrated reductions in pill burden of approximately $50 \%[14,17,18]$. Given its high potency in binding phosphate [15], SO use may enable a less restrictive protein diet, leading to correction of hypoalbuminemia and PEW. The current analysis investigates temporal changes in sP and nutritional parameters among hypoalbuminemic (hypoAlb) HD patients prescribed SO as part of routine clinical care. We hypothesized that $\mathrm{SO}$ would reduce $\mathrm{sP}$ while allowing for improvement in albumin concentration secondary to changes in dietary intake of protein and/or changes in gastrointestinal symptoms.

\section{Methods}

\section{Study design}

This retrospective cohort study utilized de-identified data extracted from the Fresenius Kidney Care clinical data warehouse and a renal pharmacy service (FreseniusRx) database.
Adult, in-center HD patients prescribed SO monotherapy as part of routine care and continued SO therapy for $\geq 12$ months were included. Treatment periods were defined as baseline (-Q2, -Q1; 3-month periods before $\mathrm{SO}$ ) and $\mathrm{SO}$ therapy (Q1 to Q4; 12 months of SO). The hypoAlb cohort included patients with sAlb $\leq 3.5 \mathrm{~g} / \mathrm{dL}$ at baseline (-Q2 or Q1). All patients were required to have information on age, sex, race, body mass index, and diabetes status. A reference group of non-hypoalbuminemic (NhypoAlb; sAlb $>3.5 \mathrm{~g} / \mathrm{dL}$ at baseline) patients was selected with individuals matched to the hypoAlb cohort in a 1:1 ratio on age ( \pm 5 years), sex, self-reported race, body mass index $\left( \pm 2 \mathrm{~kg} / \mathrm{m}^{2}\right)$, and diabetes status.

\section{Clinical variables and statistical analysis}

Clinical parameters of interest included PB pill burden, sP, nutritional markers (sAlb, equilibrated nPCR, weight, and serum creatinine), equilibrated $\mathrm{Kt} / \mathrm{V}$, intact parathyroid hormone (iPTH) levels, and corrected serum calcium. SAlb and nPCR were each divided by $\mathrm{sP}$ to calculate phosphorus-attuned variables, allowing assessment of the impact of lowering sP without restricting dietary protein intake [18]. Laboratory tests repeated within a month were averaged to overcome short-term measurement variability. Changes in quarterly clinical markers before and after SO switch were examined using linear mixed models to account for repeated measurements. Summary statistics (monthly and quarterly) were presented as least-square (LS) means and standard error (SE). $P$ values compared estimates across treatment quarters. Given the limited number of hypoAlb patients in the database meeting elgibility requirements, development of an NhypoAlb cohort matched on additional, potentially confounding variables (e.g., baseline PB) was deemed impractical. As such, formal analyses comparing the hypoAlb and NhypoAlb cohorts were not performed.

\section{Results}

Seventy-nine hypoAlb patients switched to SO were identified in the database; most patients were receiving calcium acetate- or sevelamer-based PBs at baseline. Twelve (15\%) of these patients had been undergoing dialysis for fewer than 120 days. Clinical parameters at baseline and across SO follow-up among patients with baseline hypoAlb are presented in Table 2. Prior to SO (-Q1), the mean sP concentration was $6.79 \mathrm{mg} / \mathrm{dL}$ and the mean sAlb level was $3.50 \mathrm{~g} / \mathrm{dL}$. At -Q1, sP concentrations $\leq 4.5 \mathrm{mg} / \mathrm{dl}$ and $\leq 5.5 \mathrm{mg} / \mathrm{dl}$ were 2.5 and $24.1 \%$ of patients, respectively. At all SO therapy follow-up timepoints, patients in the hypoAlb group demonstrated significant reductions from baseline in $\mathrm{PB}$ pill burden and sP. At Q4, patients achieving sP concentrations $\leq$ $4.5 \mathrm{mg} / \mathrm{dl}$ and $\leq 5.5 \mathrm{mg} / \mathrm{dl}$ were 15.2 and $38.0 \%$, respectively. A mean sAlb increase of $0.18 \mathrm{~g} / \mathrm{dL}$ was observed 
during SO treatment. Concurrent with SO therapy, significant increases in pre- and post-dialysis weight were observed for the hypoAlb cohort.

By design, the NhypoAlb reference group had similar age, sex, race, body mass index, and diabetes status distribution as the hypoAlb cohort. Prior to SO (-Q1), sP concentrations $\leq 4.5 \mathrm{mg} / \mathrm{dl}$ and $\leq 5.5 \mathrm{mg} / \mathrm{dl}$ were 1.3 and $13.9 \%$ of patients, respectively. As detailed in Table 1, mean dialysis vintage was longer for the NhypoAlb patients than for the hypoAlb group (45.3 vs 34.7 months). Significant reductions from baseline in PB pill burden and $\mathrm{sP}$ were observed at all $\mathrm{SO}$ therapy timepoints (Table 3). At Q4, patients achieving sP concentrations $\leq$ $4.5 \mathrm{mg} / \mathrm{dl}$ and $\leq 5.5 \mathrm{mg} / \mathrm{dl}$ were 15.2 and $30.4 \%$, respectively. In contrast to hypoAlb patients, sAlb levels remained unchanged (approximately $4.0 \mathrm{~g} / \mathrm{dL}$ ) throughout most of the SO follow-up period (at Q4, a small but

Table 1 Demographic characteristics

\begin{tabular}{|c|c|c|}
\hline Characteristic & $\begin{array}{l}\text { hypoAlb patients } \\
(n=79)\end{array}$ & $\begin{array}{l}\text { NhypoAlb patients } \\
(n=79)\end{array}$ \\
\hline Age, years & 54.9 & 55.1 \\
\hline Dialysis vintage, months & 34.7 & 45.3 \\
\hline Incident HD patients, ${ }^{a} \%$ & $15.2 \%$ & $3.8 \%$ \\
\hline Male, \% & $53.2 \%$ & $53.2 \%$ \\
\hline \multicolumn{3}{|l|}{ Race, \% } \\
\hline Black & $35.4 \%$ & $35.4 \%$ \\
\hline White & $62.0 \%$ & $62.0 \%$ \\
\hline Other & $2.6 \%$ & $2.6 \%$ \\
\hline Hispanic/Latino, \% & $11.4 \%$ & $26.6 \%$ \\
\hline $\mathrm{BMI}, \mathrm{kg} / \mathrm{m}^{2}$ & 31.4 & 31.3 \\
\hline Baseline PB not recorded, \% & $34.2 \%$ & $26.6 \%$ \\
\hline \multicolumn{3}{|l|}{ Baseline PB recorded, \% } \\
\hline Calcium acetate (CaAc) & $26.6 \%$ & $24.1 \%$ \\
\hline Sevelamer (Sev) & $36.7 \%$ & $48.1 \%$ \\
\hline Lanthanum carbonate & $1.3 \%$ & $1.3 \%$ \\
\hline Switch between Sev/CaAc & $1.3 \%$ & $0.0 \%$ \\
\hline \multicolumn{3}{|l|}{ Primary cause of ESRD, $\%$} \\
\hline Diabetes & $54.4 \%$ & $40.5 \%$ \\
\hline Hypertension & $21.5 \%$ & $34.2 \%$ \\
\hline Glomerulonephritis & $7.6 \%$ & $8.9 \%$ \\
\hline Polycystic kidney & $0.0 \%$ & $1.3 \%$ \\
\hline Other/ unknown & $16.4 \%$ & $15.2 \%$ \\
\hline \multicolumn{3}{|l|}{ Comorbid conditions, $\%$} \\
\hline Diabetes & $63.3 \%$ & $63.3 \%$ \\
\hline Congestive heart failure & $21.5 \%$ & $20.3 \%$ \\
\hline
\end{tabular}

Summary statistics are presented as mean or percentage Abbreviations: $B M I$ body mass index, ESRD end-stage renal disease, $H D$ hemodialysis, hypoAlb hypoalbuminemic, NhypoAlb non-hypoalbuminemic, $P B$ phosphate binder, SO sucroferric oxyhydroxide

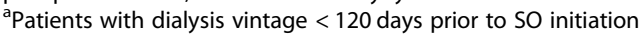

statistically significant reduction was observed). Additionally, the NhypoAlb cohort failed to demonstrate significant changes in serum creatinine or body weight (with the exception of a small increase in pre-dialysis weight observed at Q1). Given the differences in dialysis vintage of patients in the 2 study populations, a sensitivity analysis excluding 14 matched pairs where $\geq 1$ patient had dialysis vintage $<120$ days was performed. It revealed mean sAlb changes from baseline of $+0.12 \mathrm{~g} / \mathrm{dL}$ and $+0.02 \mathrm{~g} / \mathrm{dL}$ for hypoAlb and NhypoAlb patients, respectively.

For each group, the monthly means of clinical parameters are presented in Fig. 1 (sP, sAlb, and serum creatinine), Fig. 2 (pre- and post-dialysis weight, nPCR, and HD adequacy), and Fig. 3 (phosphorus-attuned albumin and nPCR). The initiation of SO therapy in the hypoAlb cohort was associated with marked decreases in $\mathrm{sP}$ and pill burden, yet sAlb continued to rise before plateauing (Fig. 1, Table 2, baseline: $3.50 \mathrm{~g} / \mathrm{dL}$; SO follow-up: $3.69-$ $3.74 \mathrm{~g} / \mathrm{dL} ; \quad P<0.0001)$. Pre-dialysis and post-dialysis weight increases were observed in the hypoAlb cohort (Fig. 2, Table 3, pre-dialysis weight: baseline, $89.1 \mathrm{~kg}$; SO follow-up, 90.2-92.5 kg; $P<0.05$ [Q1]; $P<0.0001$ [Q2Q4]; post-dialysis weight: baseline, $86.3 \mathrm{~kg}$; $\mathrm{SO}$ followup, 87.3-89.5 kg; $P<0.05$ [Q1]; $P<0.0001$ [Q2-Q4]). In addition, increases in phosphorus-attuned nPCR and albumin were observed in both groups (Fig. 3).

\section{Discussion}

In this retrospective cohort study, we found that the initiation of $\mathrm{SO}$ resulted in significant reduction in $\mathrm{SP}$ concentrations and daily PB pill burden in patients with low and normal sAlb levels at baseline. As observed in prior studies [16, 19-21], and independent of baseline sAlb status, SO effectively reduced sP, with a 55 to $56 \%$ decrease in mean daily PB pill burden (Table 2 and Table 3 ). Despite reduced sP levels following the initiation of $\mathrm{SO}$, the sAlb concentration continued to rise before plateauing in patients who were hypoalbuminemic at baseline. This observation may have important clinical implications for lowering the risk of PEW and improving patient outcomes.

Baseline data demonstrated that hypoAlb patients had lower sP, PB pill burden, and $\mathrm{nPCR}$ than patients in the reference group (Fig. 1, Fig. 2, and Table 1), suggesting an increased reliance on protein restriction for phosphate control. Sharp increases in mean equilibrated nPCR during months -5 to -3 (Fig. 2), increases in mean serum creatinine during months -5 to -1 (Fig. 1), and subsequent increases in sAlb in month -1 (Fig. 1) suggest that patients increased their protein intake at the "expense" of elevated sP (Fig. 1), as also evidenced by decreasing phosphorus-attuned albumin (Fig. 3).

There are no data or mechanistic hypotheses to suggest that SO therapy directly impacts protein handling 


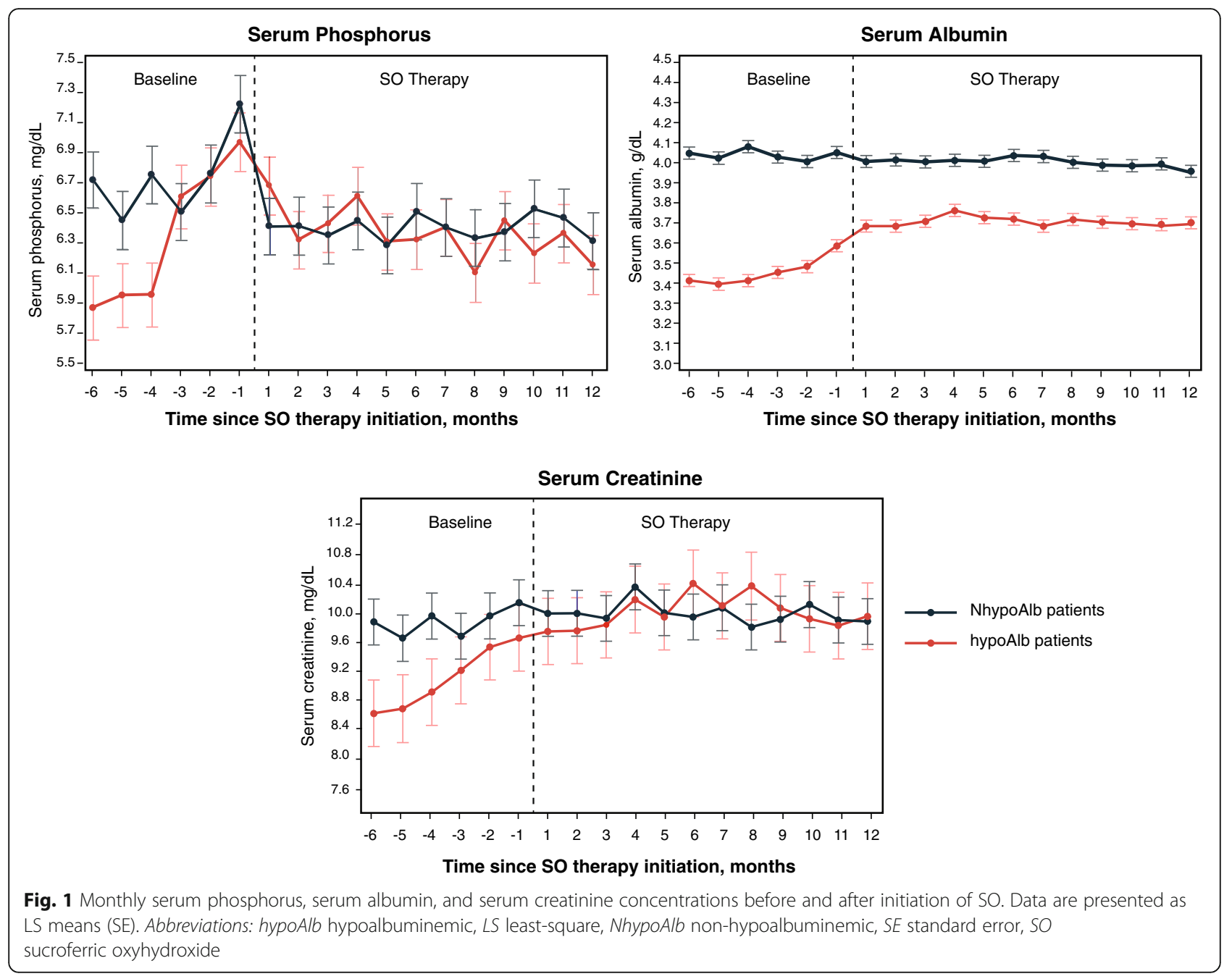

or appetite in patients. Instead, the improvements in sAlb and progressive weight increases observed in the hypoAlb cohort during SO therapy likely resulted from continued increases in protein intake, as suggested by small increases in phosphorus-attuned nPCR. Such changes may be the result of dietary counseling (e.g., accompanying the initiation of $\mathrm{SO}$ and $\mathrm{sP}$ lowering). It is also possible that the higher baseline PB pill burden impaired appetite and overall nutritional intake as a result of gastrointestinal side effects [11], and the switch to SO may have allowed for improved nutritional intake. In a recent meta-analysis, sevelamer was associated with $32 \%$ more gastrointestinal side effects than SO $(P=0.0001)$ [22]. Furthermore, in 2 active-controlled, pivotal trials, SO was associated with fewer reports of decreased appetite than sevelamer (1.9\% vs $4.3 \%)$ [23]. The reduced pill burden and increased potency [11] associated with SO and/or its non-resin-based formulation (52/79 hypoAlb patients on baseline PB: $56 \%$ sevelamer, $40 \%$ calcium acetate, $4 \%$ other) may not negatively impact appetite to the extent observed with other PBs.
Increasing sAlb has been reported to improve patient outcomes. For instance, it has been proposed that increasing sAlb $>3.8 \mathrm{~g} / \mathrm{dL}$ among US HD patients might prevent $\sim 10,000$ deaths annually [24]. Temporal decreases in sP with concomitant increases in sAlb have been associated with a survival benefit of 8 to 9\% [4]. More recently, use of a $\mathrm{PB}$ that improves nutritional markers such as sAlb and nPCR was associated with a significant reduction in mortality [25]. There are also data to suggest that allowing unrestricted dietary protein intake by HD patients may improve survival [5].

The results of the present study highlight the challenging nature of phosphate control among HD populations. While the percentage of patients attaining $\mathrm{sP} \leq 5.5 \mathrm{mg} / \mathrm{dl}$ and $\leq 4.5 \mathrm{mg} / \mathrm{dl}$ increased in our study, the therapeutic approach to managing and preventing hyperphosphatemia should not be limited to PB pharmacotherapy. Appropriate dietary counseling and HD adequacy should also be employed [26].

The observational nature of this analysis provides valuable information from a real-world cohort of patients 

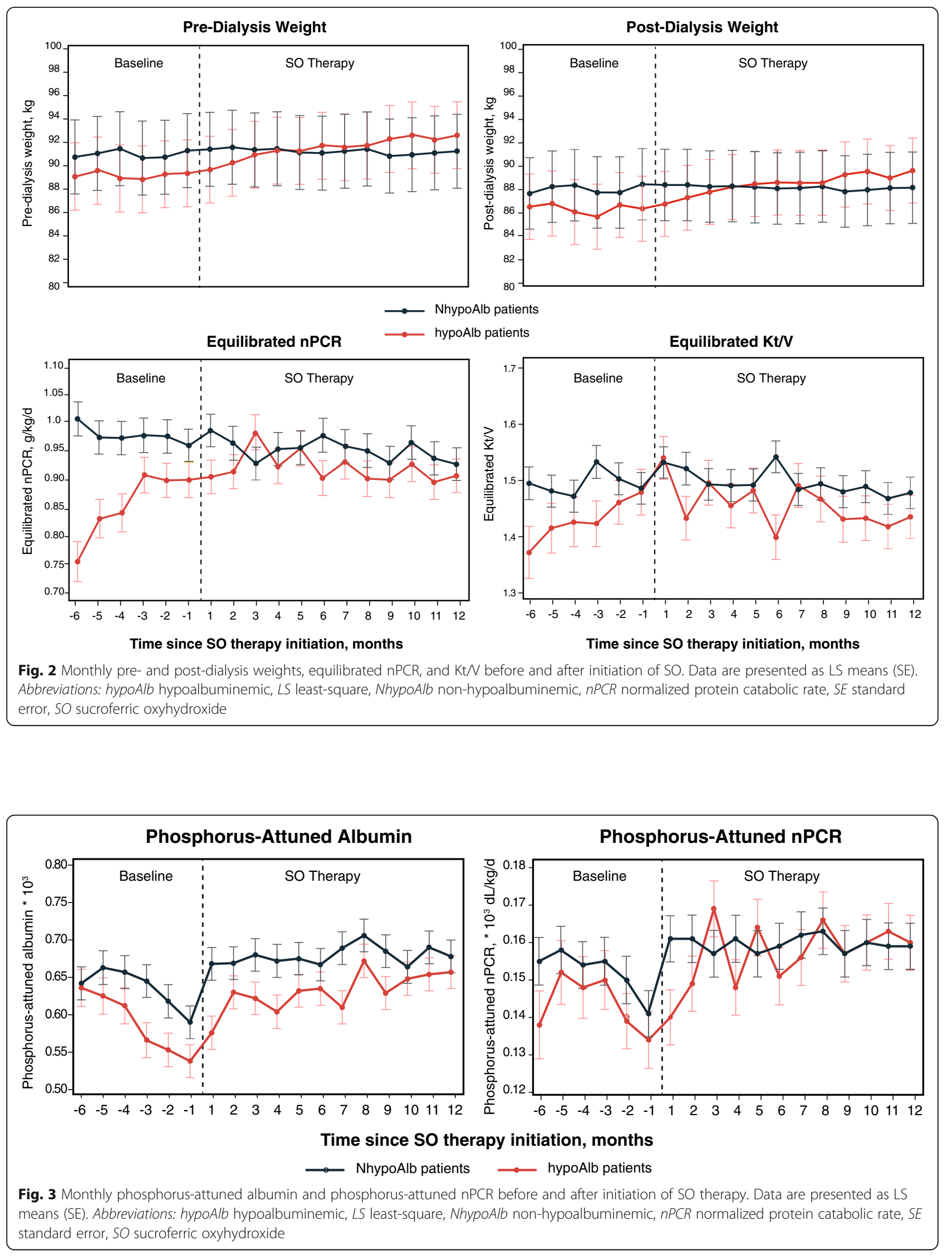
Table 2 Changes in clinical parameters from baseline in hypoalbuminemic patients

\begin{tabular}{|c|c|c|c|c|c|c|c|}
\hline \multirow[t]{2}{*}{ Parameter } & \multicolumn{2}{|l|}{ Baseline } & \multicolumn{4}{|l|}{ SO therapy } & \multirow{2}{*}{$\begin{array}{l}\text { Mean change } \\
\text { from baseline }\end{array}$} \\
\hline & $-\mathrm{Q} 2$ & $-\mathrm{Q} 1$ & Q1 & Q2 & Q3 & Q4 & \\
\hline PB pills/d & $7.9[0.2]^{\mathrm{a}}$ & $8.9[0.2]$ & $3.9[0.2]^{a}$ & $4.0[0.2]^{a}$ & $4.0[0.2]^{\mathrm{a}}$ & $4.1[0.2]^{a}$ & $-4.9[0.5]^{a}$ \\
\hline sP (mg/dL) & $5.93[0.16]^{\mathrm{a}}$ & $6.79[0.15]$ & $6.48[0.15]^{c}$ & $6.41[0.15]^{c}$ & $6.33[0.15]^{b}$ & $6.25[0.15]^{\mathrm{a}}$ & $-0.40[0.11]^{c}$ \\
\hline sAlb (g/dL) & $3.41[0.03]^{\mathrm{a}}$ & $3.50[0.03]$ & $3.69[0.03]^{a}$ & $3.74[0.03]^{a}$ & $3.70[0.03]^{a}$ & $3.69[0.03]^{a}$ & $+0.18[0.03]^{\mathrm{a}}$ \\
\hline $\mathrm{nPCR}(\mathrm{g} / \mathrm{kg} / \mathrm{d})$ & $0.81[0.03]^{\mathrm{a}}$ & $0.90[0.03]$ & $0.93[0.02]^{\text {ns }}$ & $0.93[0.02]^{\text {ns }}$ & $0.91[0.02]^{\mathrm{ns}}$ & $0.91[0.02]^{\text {ns }}$ & $+0.03[0.02]^{\mathrm{ns}}$ \\
\hline Phosphorus-attuned albumin $\left(\times 10^{3}\right)$ & $0.62[0.01]^{a}$ & $0.55[0.01]$ & $0.61[0.01]^{\mathrm{a}}$ & $0.62[0.01]^{\mathrm{a}}$ & $0.64[0.01]^{\mathrm{a}}$ & $0.65[0.01]^{\mathrm{a}}$ & $+0.08[0.01]^{a}$ \\
\hline Phosphorus-attuned nPCR $\left(\times 10^{3} \mathrm{dL} / \mathrm{kg} / \mathrm{d}\right)$ & $0.15[0.02]^{\mathrm{ns}}$ & $0.14[0.02]$ & $0.15[0.02]^{c}$ & $0.15[0.02]^{c}$ & $0.16[0.02]^{b}$ & $0.16[0.02]^{a}$ & $+0.02[0.01]^{\mathrm{a}}$ \\
\hline Pre-dialysis weight (kg) & $89.2[2.8]^{\mathrm{ns}}$ & $89.1[2.8]$ & $90.2[2.8]^{\mathrm{C}}$ & $91.4[2.8]^{\mathrm{a}}$ & $91.8[2.8]^{\mathrm{a}}$ & $92.5[2.8]^{a}$ & $+2.2[2.2]^{a}$ \\
\hline Post-dialysis weight (kg) & $86.5[2.8]^{\mathrm{ns}}$ & $86.3[2.8]$ & $87.3[2.8]^{c}$ & $88.5[2.8]^{a}$ & $88.9[2.8]^{a}$ & $89.5[2.8]^{\mathrm{a}}$ & $+2.1[1.7]^{\mathrm{a}}$ \\
\hline Equilibrated Kt/N & $1.41[0.03]^{\mathrm{ns}}$ & $1.45[0.03]$ & $1.49[0.03]^{\mathrm{ns}}$ & $1.45[0.03]^{\mathrm{ns}}$ & $1.47[0.03]^{\mathrm{ns}}$ & $1.43[0.03]^{\mathrm{ns}}$ & $+0.014[0.02]^{\mathrm{ns}}$ \\
\hline Serum creatinine (mg/dL) & $8.7[0.4]^{b}$ & $9.4[0.4]$ & $9.7[0.4]^{\mathrm{ns}}$ & $10.0[0.4]^{\mathrm{b}}$ & $10.0[0.4]^{b}$ & $9.8[0.4]^{c}$ & $+0.6[0.6]^{b}$ \\
\hline iPTH (pg/mL) & $528[43]^{\text {ns }}$ & $568[42]$ & $569[41]^{\mathrm{ns}}$ & $552[41]^{\text {ns }}$ & $579[41]^{\mathrm{ns}}$ & $536[41]^{\mathrm{ns}}$ & $-17[45]^{\mathrm{ns}}$ \\
\hline Corrected calcium (mg/dL) & $9.3[0.1]^{\mathrm{ns}}$ & $9.3[0.1]$ & $9.3[0.1]^{\mathrm{ns}}$ & $9.2[0.1]^{c}$ & $9.2[0.1]^{c}$ & $9.2[0.1]^{c}$ & $-0.08[0.1]^{\mathrm{ns}}$ \\
\hline
\end{tabular}

Summary statistics are expressed as LS means [standard errors]

Abbreviations: $i P T H$ intact parathyroid hormone, $L S$ least-square, $n P C R$ normalized protein catabolic rate, $n s$ non-significant, $P B$ phosphate binder, $s A l b$ serum albumin, $S O$ sucroferric oxyhydroxide, $S P$ serum phosphorus

All comparisons were carried out with $-\mathrm{Q} 1$ as the reference. ${ }^{\mathrm{a}} P<0.0001,{ }^{\mathrm{b}} P<0.001,{ }^{\mathrm{c}} P<0.05$, ${ }^{\mathrm{ns}}$ non-significant

treated in HD practices across the United States, but the results should be interpreted in the context of several limitations. Although a reference group was included, matching was performed only on the basis of 5 characteristics and therefore prevented the establishment of an appropriate control group. Differences in baseline PB use and dietary status did not influence inclusion in the reference group. A causal relationship between $\mathrm{SO}$ and improved nutritional markers cannot be established, given the observational nature of this analysis. Beyond the initiation of therapy with $\mathrm{SO}$, changes in nutritional counseling or concomitant illness may have influenced observed laboratory changes. Additionally, the analysis did not account for factors capable of impacting sAlb, such as acute-phase reactants or residual renal function [7, 27]. Future prospective studies may consider the addition of bioimpedance and dietary intake measures as a follow-up to this retrospective database study. Body composition data from bioimpedance measurements may be helpful to investigate the nature of the body weight increase observed in hypoalbuminemic patients (e.g. lean tissue mass, adipose tissue mass, excess fluid),

Table 3 Changes in clinical parameters from baseline in non-hypoalbuminemic patients

\begin{tabular}{|c|c|c|c|c|c|c|c|}
\hline \multirow[t]{2}{*}{ Parameter } & \multicolumn{2}{|l|}{ Baseline } & \multicolumn{4}{|l|}{ SO therapy } & \multirow{2}{*}{$\begin{array}{l}\text { Mean change } \\
\text { from baseline }\end{array}$} \\
\hline & $-\mathrm{Q} 2$ & $-\mathrm{Q} 1$ & Q1 & Q2 & Q3 & Q4 & \\
\hline PB pills/d & $8.4[0.2]^{c}$ & $8.9[0.2]$ & $3.7[0.2]^{a}$ & $3.8[0.2]^{\mathrm{a}}$ & $3.8[0.2]^{a}$ & $3.8[0.2]^{a}$ & $-5.0[0.5]^{\mathrm{a}}$ \\
\hline$s P(m g / d L)$ & $6.65[0.16]^{\mathrm{ns}}$ & $6.83[0.16]$ & $6.39[0.16]^{\mathrm{a}}$ & $6.41[0.16]^{\mathrm{a}}$ & $6.37[0.16]^{\mathrm{a}}$ & $6.43[0.16]^{b}$ & $-0.51[0.12]^{a}$ \\
\hline sAlb (g/dL) & $4.05[0.02]^{\mathrm{ns}}$ & $4.03[0.02]$ & $4.01[0.02]^{\mathrm{ns}}$ & $4.02[0.02]^{\mathrm{ns}}$ & $4.01[0.02]^{\text {ns }}$ & $3.97[0.02]^{c}$ & $-0.02[0.03]^{\mathrm{ns}}$ \\
\hline $\mathrm{nPCR}(\mathrm{g} / \mathrm{kg} / \mathrm{d})$ & $0.98[0.02]^{\mathrm{ns}}$ & $0.97[0.02]$ & $0.96[0.02]^{\mathrm{ns}}$ & $0.96[0.02]^{\mathrm{ns}}$ & $0.95[0.02]^{\mathrm{ns}}$ & $0.94[0.02]^{\mathrm{ns}}$ & $-0.02[0.02]^{\mathrm{ns}}$ \\
\hline Phosphorus-attuned albumin $\left(\times 10^{3}\right)$ & $0.65[0.02]^{c}$ & $0.62[0.02]$ & $0.67[0.02]^{a}$ & $0.67[0.02]^{a}$ & $0.69[0.02]^{a}$ & $0.68[0.02]^{a}$ & $+0.06[0.01]^{\mathrm{a}}$ \\
\hline Phosphorus-attuned nPCR $\left(\times 10^{3} \mathrm{dL} / \mathrm{kg} / \mathrm{d}\right)$ & $0.16[0.01]^{\mathrm{ns}}$ & $0.15[0.01]$ & $0.16[0.01]^{\mathrm{c}}$ & $0.16[0.01]^{c}$ & $0.16[0.01]^{\mathrm{b}}$ & $0.16[0.01]^{c}$ & $+0.01[0.01]^{c}$ \\
\hline Pre-dialysis weight (kg) & $91.1[3.2]^{\mathrm{ns}}$ & $90.9[3.2]$ & $91.4[3.2]^{c}$ & $91.2[3.2]^{\mathrm{ns}}$ & $91.2[3.2]^{\text {ns }}$ & $91.1[3.2]^{\mathrm{ns}}$ & $+0.5[0.4]^{\mathrm{ns}}$ \\
\hline Post-dialysis weight (kg) & $88.2[3.1]^{\mathrm{ns}}$ & $88.1[3.1]$ & $88.4[3.1]^{\mathrm{ns}}$ & $88.3[3.1]^{\mathrm{ns}}$ & $88.2[3.1]^{\text {ns }}$ & $88.2[3.1]^{\text {ns }}$ & $+0.4[0.4]^{\mathrm{ns}}$ \\
\hline Equilibrated Kt/N & $1.48[0.02]^{\mathrm{ns}}$ & $1.51[0.02]$ & $1.52[0.02]^{\mathrm{ns}}$ & $1.51[0.02]^{\mathrm{ns}}$ & $1.49[0.02]^{\mathrm{ns}}$ & $1.48[0.02]^{\mathrm{ns}}$ & $-0.008[0.02]^{\mathrm{ns}}$ \\
\hline Serum creatinine (mg/dL) & $9.7[0.3]^{\mathrm{ns}}$ & $9.8[0.3]$ & $9.9[0.3]^{\mathrm{ns}}$ & $10.0[0.3]^{\mathrm{ns}}$ & $9.8[0.3]^{\mathrm{ns}}$ & $9.8[0.3]^{\mathrm{ns}}$ & $+0.08[0.1]^{\mathrm{ns}}$ \\
\hline iPTH (pg/mL) & $609[64]^{\mathrm{ns}}$ & $633[64]$ & $651[63]^{\text {ns }}$ & $656[63]^{\mathrm{ns}}$ & $643[63]^{\text {ns }}$ & $763[63]^{b}$ & $+49[44]^{\mathrm{ns}}$ \\
\hline Corrected calcium (mg/dL) & $9.1[0.07]^{\mathrm{ns}}$ & $9.2[0.07]$ & $9.2[0.07]^{\mathrm{ns}}$ & $9.1[0.07]^{\mathrm{ns}}$ & $9.1[0.07]^{\mathrm{ns}}$ & $9.1[0.07]^{\mathrm{ns}}$ & $-0.04[0.05]^{\mathrm{ns}}$ \\
\hline
\end{tabular}

Summary statistics are expressed as LS means [standard errors]

Abbreviations: $i P T H$ intact parathyroid hormone, $L S$ least-square, $n P C R$ normalized protein catabolic rate, $n s$ nonsignificant, $P B$ phosphate binder, $s A l b$ serum albumin, $S O$ sucroferric oxyhydroxide, $S P$ serum phosphorus

All comparisons were carried out with $-\mathrm{Q} 1$ as the reference. ${ }^{\mathrm{a}} P<0.0001,{ }^{\mathrm{b}} P<0.001,{ }^{\mathrm{c}} P<0.05$, ${ }^{\mathrm{ns}}$ non-significant 
and self-reported measures of dietary intake such as a dietary diary may help to fully capture dietary changes, and dietary intake of proteins.

\section{Conclusion}

SO was associated with significant reductions in $\mathrm{sP}$ levels and PB pill burden in a real-world cohort of $\mathrm{HD}$ patients. As evidenced by sustained improvements in nutritional status, SO may be particularly helpful for the control of sP in those HD patients exhibiting evidence of protein malnutrition (i.e., reduced sAlb) by allowing moderation of dietary protein restriction.

\section{Abbreviations}

BMl: Body mass index; ESRD: End-stage renal disease; HD: Hemodialysis; hypoAlb: Hypoalbuminemic; iPTH: Intact parathyroid hormone; LS: Leastsquare; NhypoAlb: Non-hypoalbuminemic; nPCR: Normalized protein catabolic rate; ns: Non-significant; PB: Phosphate binder; PEW: Protein-energy wasting; sAlb: Serum albumin; SE: Standard error; SO: Sucroferric oxyhydroxide; sP: Serum phosphorus

\section{Acknowledgements}

Medical writing and editing support was provided by Adam Perahia, MD, of NorthStar Strategic Consulting, LLC, via funding by Fresenius Medical Care Renal Therapies Group.

\section{Authors' contributions}

KK-Z contributed to the conception and design of the study, interpretation of results, and revisions to the manuscript, and provided expertise on nutrition and nutrition markers. LHF contributed to the conception and design of the study, data analysis, interpretation of results, and revisions to the manuscript. VP contributed to the design of the study, performed data analysis and interpretation, and revised the manuscript. NVA contributed to the conception of the study and provided clinical insights, interpretation of results, and revisions to the manuscript. CM contributed to the conception and design of the study, interpretation of results, and revisions to the manuscript. RJK contributed to the interpretation of results and revisions to the manuscript, and provided clinical insights as a nephrologist. DWC contributed to the interpretation of results and critical revisions to the manuscript, and provided expertise on mineral bone disorders in dialysis patients. All authors have approved the final version of the submitted manuscript and accept accountability for the overall work by ensuring that questions pertaining to the accuracy or integrity of any portion of the work are appropriately investigated and resolved.

\section{Funding}

Fresenius Medical Care North America Renal Therapies Group provided funding for the study and is the distributor in the United States of the drug that is the subject of the research. Employees of Fresenius Medical Care Renal Therapies Group were involved in the design, analysis, interpretation of results, and writing. Fresenius Kidney Care is a dialysis provider and data for the study were from the Fresenius Medical Care clinical data warehouse.

\section{Availability of data and materials}

We encourage investigators interested in data sharing and collaboration to contact the corresponding author.

\section{Ethics approval and consent to participate}

This manuscript reports data from a retrospective analysis. The need for informed consent was waived by the New England Institutional Review Board (Needham, Massachusetts) because of the anonymous and purely observational nature of the study.

\section{Consent for publication}

Not applicable.

\section{Competing interests}

LHF, VP, CM, and RJK are employees of Fresenius Medical Care Renal Therapies Group. LHF, CM, and RJK own stock in Fresenius Medical Care North America. RJK is on the Board of Directors of Advanced Renal Technologies. DWC is a consultant and speaker for Fresenius Medical Care. KK-Z has received honoraria and/or support from Abbott, AbbVie, Alexion, American Society of Nephrology, Amgen, AstraZeneca, AVEO, Chugai, DaVita, Fresenius, Fresenius Kabi, Genentech, Haymarket Media, Hofstra Medical School, Hospira, International Federation of Kidney Foundations, International Society for Hemodialysis, International Society of Renal Nutrition and Metabolism, Japanese Society for Dialysis Therapy, Keryx, National Institutes of Health, National Kidney Foundation, Novartis, OPKO, Pfizer, Relypsa, Resverlogix, Sandoz, Sanofi, Shire, UpToDate, Vifor, and ZS Pharma. NVA received honoraria for advisory boards from Fresenius Medical Care and Mallinckrodt and is a speaker for Mallinckrodt.

\section{Author details}

'Irvine School of Medicine, University of California, Orange, CA, USA. ${ }^{2}$ Fresenius Medical Care Renal Therapies Group, Waltham, MA, USA. ${ }^{3}$ Renal Medical Care PC, Brockton, MA, USA. ${ }^{4}$ Washington University School of Medicine, 660 S. Euclid Ave., CB 8129, St. Louis, MO 63110, USA.

Received: 23 July 2019 Accepted: 3 October 2019

Published online: 29 October 2019

\section{References}

1. US-DOPPS (Dialysis Outcomes and Practice Patterns Study) Practice Monitor Serum phosphorous (most recent). April 2019. https://www.dopps.org/DPM/ Files/phosphmgdl_c_overallTAB.htm. Accessed 8 July 2019.

2. Zitt E, Lamina C, Sturm G, et al. Interaction of time-varying albumin and phosphorus on mortality in incident dialysis patients. Clin J Am Soc Nephrol. 2011;6(11):2650-6.

3. Hou Y, Li X, Sun L, Qu Z, Jiang L, Du Y. Phosphorus and mortality risk in end-stage renal disease: a meta-analysis. Clin Chim Acta. 2017;474:108-13.

4. Shinaberger CS, Greenland S, Kopple JD, et al. Is controlling phosphorus by decreasing dietary protein intake beneficial or harmful in persons with chronic kidney disease? Am J Clin Nutr. 2008;88(6):1511-8.

5. Lynch KE, Lynch R, Curhan GC, Brunelli SM. Prescribed dietary phosphate restriction and survival among hemodialysis patients. Clin J Am Soc Nephrol. 2011;6(3):620-9.

6. Sinha A, Prasad N. Dietary management of hyperphosphatemia in chronic kidney disease. Clinical Queries: Nephrology. 2014;3(1):38-45.

7. Kaysen GA, Don BR. Factors that affect albumin concentration in dialysis patients and their relationship to vascular disease. Kidney Int Suppl. 2003;84: 594-7.

8. Sridhar NR, Josyula S. Hypoalbuminemia in hemodialyzed end stage renal disease patients: risk factors and relationships-a 2 year single center study. BMC Nephrol. 2013;14:242

9. Eriguchi R, Obi Y, Streja E, et al. Longitudinal associations among renal urea clearance-corrected normalized protein catabolic rate, serum albumin, and mortality in patients on hemodialysis. Clin J Am Soc Nephrol. 2017;12(7): 1109-17.

10. Feroze $U$, Noori N, Kovesdy CP, et al. Quality-of-life and mortality in hemodialysis patients: roles of race and nutritional status. Clin J Am Soc Nephrol. 2011;6(5):1100-11.

11. Gutekunst L. An update on phosphate binders: a dietitian's perspective. J Ren Nutr. 2016;26(4):209-18.

12. Lodebo BT, Shah A, Kopple JD. Is it important to prevent and treat proteinenergy wasting in chronic kidney disease and chronic dialysis patients? J Ren Nutr. 2018;28(6):369-79.

13. Fouque D, Horne R, Cozzolino M, Kalantar-Zadeh K. Balancing nutrition and serum phosphorus in maintenance dialysis. Am J Kidney Dis. 2014;64(1): $143-50$.

14. Sprague SM, Floege J. Sucroferric oxyhydroxide for the treatment of hyperphosphatemia. Expert Opin Pharmacother. 2018;19(10):1137-48.

15. Velphoro (sucroferric oxyhydroxide) [package insert]. Waltham, MA: Fresenius Medical Care North America; 2018. https://www.accessdata.fda. gov/drugsatfda_docs/label/2018/205109s006lbl.pdf

16. Floege J, Covic AC, Ketteler M, et al. One-year efficacy and safety of the iron-based phosphate binder sucroferric oxyhydroxide in patients on peritoneal dialysis. Nephrol Dial Transplant. 2017;32(11):1918-26. 
17. Coyne DW, Ficociello LH, Parameswaran V, et al. Real-world effectiveness of sucroferric oxyhydroxide in patients on chronic hemodialysis: a retrospective analysis of pharmacy data. Clin Nephrol. 2017;88(8):59-67.

18. Kalantar-Zadeh $\mathrm{K}$, Parameswaran V, Ficociello LH, et al. Real-world scenario improvements in serum phosphorus levels and pill burden in peritoneal dialysis patients treated with sucroferric oxyhydroxide. Am J Nephrol. 2018; 47(3):153-61.

19. Floege J, Covic AC, Ketteler M, et al. Long-term effects of the iron-based phosphate binder, sucroferric oxyhydroxide, in dialysis patients. Nephrol Dial Transplant. 2015;30(6):1037-46.

20. Koiwa F, Terao A. Dose-response efficacy and safety of PA21 in Japanese hemodialysis patients with hyperphosphatemia: a randomized, placebocontrolled, double-blind, phase II study [published correction appears in Clin Exp Nephrol. 2017;21(3):523]. Clin Exp Nephrol. 2017;21(3):513-22.

21. Koiwa F, Yokoyama K, Fukagawa M, Terao A, Akizawa T. Efficacy and safety of sucroferric oxyhydroxide compared with sevelamer hydrochloride in Japanese haemodialysis patients with hyperphosphataemia: a randomized, open-label, multicentre, 12-week phase III study. Nephrology (Carlton). 2017; 22(4):293-300

22. Xie D, Ye N, Li M. A systematic review on the efficacy and safety of PA21 versus sevelamer in dialysis patients. Int Urol Nephrol. 2018;50(5):905-9.

23. Velphoro (sucroferric oxyhydroxide) [product monograph]. St. Gallen, Switzerland: Vifor Fresenius Medical Care Renal Pharma Ltd.; 2018. https:// pdf.hres.ca/dpd_pm/00043058.PDF

24. Kalantar-Zadeh K, Kilpatrick RD, Kuwae N, et al. Revisiting mortality predictability of serum albumin in the dialysis population: time dependency, longitudinal changes and population-attributable fraction. Nephrol Dial Transplant. 2005;20(9):1880-8

25. Komaba H, Kakuta T, Wada T, Hida M, Suga T, Fukagawa M. Nutritional status and survival of maintenance hemodialysis patients receiving lanthanum carbonate. Nephrol Dial Transplant. 2019;34(2):318-25.

26. Barreto FC, Barreto DV, Massy ZA, Drüeke TB. Strategies for phosphate control in patients with CKD. Kidney Int Rep. 2019;4(8):1043-56.

27. Kaysen GA. Serum albumin concentration in dialysis patients: why does it remain resistant to therapy? Kidney Int. 2003;(suppl 87):S92-8.

\section{Publisher's Note}

Springer Nature remains neutral with regard to jurisdictional claims in published maps and institutional affiliations.

Ready to submit your research? Choose BMC and benefit from:

- fast, convenient online submission

- thorough peer review by experienced researchers in your field

- rapid publication on acceptance

- support for research data, including large and complex data types

- gold Open Access which fosters wider collaboration and increased citations

- maximum visibility for your research: over $100 \mathrm{M}$ website views per year

At $\mathrm{BMC}$, research is always in progress.

Learn more biomedcentral.com/submissions 